\title{
Respon Pertumbuhan dan Hasil Tanaman Selada (Lactuca sativa L.) terhadap Beberapa Dosis Pupuk Kandang Kotoran Itik pada Tanah Rawa Lebak
}

\section{(Growth and Yield Response Lettuce (Lactuca sativa L.) to Ducks Manure Fertilizer Dosages on Lebak Wetlands)}

\author{
Nur Hafizah ${ }^{1)}$ \& Fikriah $^{2)}$ \\ Program Studi Agroteknologi, Sekolah Tinggi Ilmu Pertanian Amuntai \\ 1) fifi_bjm@yahoo.co.id \\ 2) fikriah@yahoo.co.id
}

\begin{abstract}
ABSTRAK
Tanaman selada dalam proses pertumbuhan dan perkembangannya memerlukan tambahan unsur hara dengan perbaikan teknik budidaya dan perbaikan pupuk organik maupun anorganik. Pupuk organik juga disebut pupuk alami karena semua atau sebagian besar berasal dari pupuk alami. Penelitian ini bertujuan untuk (i) mengetahui respon pertumbuhan dan hasil tanaman selada terhadap pemberian pupuk kandang kotoran itik pada tanah rawa lebak, (ii) mendapatkan dosis terbaik pemberian pupuk kandang kotoran itik terhadap pertumbuhan dan hasil tanaman selada pada tanah rawa lebak. Penelitian dilaksanakan di Desa Hambuku Tengah, Kecamatan Sungai Pandan Kabupaten Hulu Sungai Utara dari bulan April - Juni 2010. Menggunakan Rancangan Acak Lengkap (RAL). Faktor yang diteliti adalah dosis pupuk kandang kotoran itik (B) sebanyak 9 perlakuan yaitu: $b_{0}=0$ t.ha ${ }^{-1} ; b_{1}=2,5$ t.ha $a^{-1} ; b_{2}=5,0$ t.ha ${ }^{-1}$; $b_{3}=7,5$ t.ha $a^{-1} ; b_{4}=10 t \cdot h a^{-1} ; b_{5}=12,5 t . h a^{-1} ; b_{6}=15,0 t . h a^{-1} ; b_{7}=17,5 t \cdot h a^{-1} ; b_{8}=20,0$ t.hat dengan 3 kali ulangan, dengan demikian terdapat 27 satuan percobaan. Peubah pengamatan yang diukur adalah tinggi tanaman dan jumlah daun umur 14, 21, 28 dan 35 hari setelah tanam (HST) dan bobot basah daun saat panen. Dari hasil penelitian terdapat respon tinggi tanaman sawi umur 28 HST dan bobot basah tanaman sawi tetapi tidak terdapat respon tinggi tanaman sawi umur 14, 21 dan 35 HST terhadap pemberian pupuk kandang kotoran itik, dengan dosis terbaik adalah perlakuan $b_{4}\left(10\right.$ t.ha $\left.{ }^{-1}\right)$.
\end{abstract}

Kata kunci: Selada, pupuk kandang, kotoran itik, rawa lebak.

\section{ABSTRACT}

Lettuce plants in the process of growth and development require additional nutrients by repair Techniques for cultivation and repair of organic or inorganic fertilizers. Organic fertilizers are also called natural fertilizers because all or most of them come from natural fertilizers. This study aims to (i) find out the effect of giving dung manure to the growth and yield of lettuce on swampy soil, (ii) get the best dose from the administration of duck manure to the growth and yield of lettuce on swampy swamp soil. This research was conducted in Hambuku Tengah Village, Sungai Pandan District from April to June 2010. Using a Completely Randomized Design (CRD). The factors studied were 9 doses of duck manure fertilizer

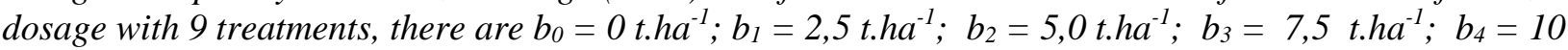

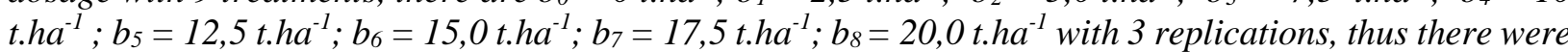
27 experimental units. The observed variables were plant height and number of leaves aged 14, 21, 28 and 35 days after planting (DAP) and leaf wet weight at harvest. From the results of the study there was a response of tall mustard plants aged 28 HST and wet weight of mustard plants but there was no response to the height of mustard plants aged 14,21 and 35 HST on the administration of duck manure, with the best dose was treatment b4 $\left(10\right.$ t.ha $\left.^{-1}\right)$.

Keywords: Lettuce, manure, duck manure, lebak wetlands.

\section{PENDAHULUAN}

Selada merupakan tanaman semusim yang termasuk ke dalam famili Asteraceae. Selada mempunyai ciri-ciri diantaranya bentuk bunganya mengumpul dalam tandan membentuk sebuah rangkaian. Selada biasanya disajikan sebagai sayur segar atau lalapan pelengkap makan. Kandungan vitamin yang terdapat di dalam daun selada di antaranya vitamin A, B dan C yang sangat 
Rawa Sains: Jurnal Sains STIPER Amuntai, Desember 2011, 1(1), 7-11.

berguna untuk kesehatan tubuh (Rukmana, 1994).

Lahan rawa lebak selain berpotensi untuk budidaya tanaman pangan seperti padi, pada umumnya juga dapat dimanfaatkan sebagai lahan budidaya sayuran khususnya selada. Hal yang menjadi permasalahan pada lahan tersebut adalah sifat kimia, biologi dan fisik tanah yang kurang menguntungkan untuk pertumbuhan tanaman selada antara lain, Pengaruh langsung kemasaman, terutama peningkatan kelarutan aluminium, besi, mangan dan hidrogen. Penurunan ketersediaan $\mathrm{P}$ karena adanya interaksi $\mathrm{P}$ besi dan aluminium. Rendahnya tanah basa-basa dan kahat hara serta salinitas (Noor, 2004).

Hasil-hasil penelitian di lahan rawa lebih menunjukkan pemberian pupuk organik berpengaruh positif terhadap hasil tanaman. Bahan organik merupakan sumber energi atau makanan bagi mikroorganisme yang mempunyai peranan penting dalam kegiatan reduksi oksidasi pada tanah sulfat masam. Bahan organik berperan dalam memperbaiki sifat tanah, tetapi sekaligus berperan dalam menekan oksidasi pirit. Bahan organik berfungsi untuk menurunkan atau mempertahankan suasana reduksi karena dapat mempertahankan kebasahan tanah sehingga oksidasi pirit dapat ditekan sehingga $\mathrm{pH}$ tanah meningkat (Direktorat Perluasan Areal, 2005).

Tanaman selada dalam proses pertumbuhan dan perkembangannya sangat memerlukan tambahan unsur hara. Terutama bila ditanam pada tanah sayuran di lahan rawa lebak di masa yang akan datang masih sangat besar (Direktorat Perluasan Areal, 2005).

Hal yang menjadi permasalahan pada lahan tersebut adalah sifat kimia yaitu peningkatan kelarutan $\mathrm{Al}, \mathrm{Fe}, \mathrm{Mn}$ dan $\mathrm{Cu}$ yang dapat meracuni tanaman bila tersedia banyak. Sifat fisik tanah yang kurang menguntungkan karena rawa lebak memiliki tekstur liat, tidak gembur dan pori tanah yang sangat kecil sehingga mikroorganisme sulit untuk hidup (Noor, 2004). Pemberian bahan organik yang berasal dari sampah organik, kotoran ternak, jerami padi, abu sekam padi atau gulma yang sudah membusuk berperan besar dalam mengurangi kelarutan unsurunsur beracun, sumber hara bagi tanaman dan sumber energi dalam menunjang aktifitas mikroorganisme tanah (Cahyono, 2005).

Peningkatan produksi tanaman pada lahan rawa lebak dapat dicapai bila dilakukan penambahan unsur hara dan perbaikan sifat tanah yaitu dengan melakukan pemberian pupuk organik seperti pupuk kendang kotoran itik.

Kabupaten Hulu Sungai Utara merupakan daerah dengan ternak itik yang lebih dikenal dengan sebutan itik alabio. Sebagian besar masyarakatnya beternak itik sehingga kotoran ternak itik dapat dimanfaatkan untuk pembuatan pupuk kandang.

Penelitian ini bertujuan untuk (i) mengetahui respon pertumbuhan dan hasil tanaman selada terhadap pemberian pupuk kandang kotoran itik pada tanah rawa lebak, (ii) mendapatkan dosis terbaik pemberian pupuk kandang kotoran itik terhadap pertumbuhan dan hasil tanaman selada pada tanah rawa lebak

\section{METODE PENELITIAN}

\section{Waktu dan Tempat Penelitian}

Penelitian di laksanakan pada bulan April - Juni 2010 bertempat di Desa Hambuku Tengah Kecamatan Sungai Pandan Kabupaten Hulu Sungai Utara Propinsi Kalimantan Selatan.

\section{Bahan dan Alat}

Bahan yang digunakan pada penelitian ini adalah pupuk kandang kotoran itik yang telah matang, media tanam berupa tanah rawa lebak, benih selada Varietas Grand Rapid, air, pestisida alami, daun rumbia, kayu, paku dan polibag. Alat yang dipergunakan antara lain cangkul, parang, gembor, gergaji, handsprayer, meteran, neraca analitik, palu, pisau, kamera dan alat tulis.

\section{Rancangan Percobaan dan Analisis Data}

Penelitian ini dilaksanakan di lapangan menggunakan Rancangan Acak Kelompok (RAK) faktor tunggal. 
Nur Hafizah \& Fikriah, Respon pertumbuhan dan hasil tanaman selada...

Pengelompokan berdasarkan tinggi bibit tanaman selada. Faktor yang diteliti adalah dosis pupuk kandang kotoran itik (B) sebanyak 9 taraf, terdiri dari: $\mathrm{b}_{0}=0$ t.ha ${ }^{-1} \approx$ $0 \quad$ g.polybag ${ }^{-1} ; \mathrm{b}_{1}=2,5$ t.ha ${ }^{-1} \approx 10$ g.polybag ${ }^{-1} ; b_{2}=5,0$ t.ha ${ }^{-1} \approx 20$ g.polybag ${ }^{-1}$ $; \mathrm{b}_{3}=7,5$ t.ha ${ }^{-1} \approx 30$ g.polybag ${ }^{-1} ; \mathrm{b}_{4}=10$ t.ha ${ }^{-1} \approx 40$ g.polybag ${ }^{-1} ; b_{5}=12,5$ t.ha $^{-1} \approx 50$ g.polybag ${ }^{-1} ; \mathrm{b}_{6}=15,0$ t.ha ${ }^{-1} \approx 60$ g.polybag ${ }^{-1}$ $; \mathrm{b}_{7}=17,5 \mathrm{t} \mathrm{ha}^{-1} \approx 70$ g.polybag ${ }^{-1} ; \mathrm{b}_{8}=20,0$ t.ha $^{-1} \approx 80$ g.polybag $^{-1}$. dengan 3 kelompok. Dengan demikian terdapat 27 satuan percobaan.

Pengamatan dilakukan terhadap tinggi tanaman dan jumlah pada umur 14, 21 dan 28 HST serta bobot basah daun saat panen. Data yang diperoleh dilakukan uji kehomogenan ragam Bartlett. Untuk mengetahui respon terhadap peubah yang diamati dilakukan analisis ragam menggunakan uji $\mathrm{F}$ pada taraf nyata $5 \%$ atau sangat nyata $1 \%$. Jika $\mathrm{F}$ hitung $>\mathrm{F}$ tabel $5 \%$ dan $1 \%$ berarti perlakuan dosis pupuk kandang kotoran itik memberikan respon nyata atau sangat nyata pada setiap peubah yang diamati, kemudian dilanjutkan dengan uji beda uji beda rata-rata menggunakan uji jarak ganda Duncan (UJGD) pada taraf uji 5\% untuk menentukan perlakuan terbaik.

\section{HASIL DAN PEMBAHASAN}

\section{Tinggi Tanaman}

Pengamatan tinggi tanaman terung dan analisis ragamnya pada umur 14, 21, 28, dan 35 HST disajikan pada Tabel 1. Berdasarkan analisis ragam diketahui bahwa tidak terdapat respon tinggi tanaman umur 14, 21 dan 35 HST tetapi memberikan respon nyata pada tinggi tanaman umur 28 HST terhadap pemberian pupuk kandang kotoran itik. Hasil uji beda uji beda rata-rata tinggi tanaman pada umur 28 HST dapat dilihat pada Tabel 1.

Tabel 1. Nilai uji beda rata-rata tinggi tanaman selada $(\mathrm{cm})$ pada umur 28 (HST)

\begin{tabular}{cc}
\hline Perlakuan & Rata-rata tinggi tanaman umur 28 HST \\
\hline $\mathrm{b}_{0}$ & $31.00_{\mathrm{a}}$ \\
$\mathrm{b}_{1}$ & $35.50_{\mathrm{a}}$ \\
$\mathrm{b}_{2}$ & $29.50_{\mathrm{a}}$ \\
$\mathrm{b}_{3}$ & $49.50_{\mathrm{b}}$ \\
$\mathrm{b}_{4}$ & $35.00_{\mathrm{a}}$ \\
$\mathrm{b}_{5}$ & $29.83_{\mathrm{a}}$ \\
$\mathrm{b}_{6}$ & $33.67_{\mathrm{a}}$ \\
$\mathrm{b}_{7}$ & $50.33_{\mathrm{b}}$ \\
$\mathrm{b}_{8}$ & $38.50_{\mathrm{a}}$ \\
\hline
\end{tabular}

Keterangan : Angka-angka yang diikuti oleh huruf yang sama tidak berbeda nyata berdasarkan DMRT pada taraf $5 \%$.

\section{Jumlah Daun}

Hasil analisis ragam menunjukkan bahwa tidak terdapat respon jumlah daun umur 14, 21, 28 dan 35 HST terhadap perlakuan pemberian dosis pupuk kandang kotoran itik.

\section{Bobot Basah Daun}

Hasil analisis ragam menunjukkan bahwa terdapat respon nyata bobot basah daun terhadap perlakuan pemberian dosis pupuk kandang kotoran itik. Hasil uji beda uji beda rata-rata rata-rata pengaruh perlakuan terhadap berat basah tanaman dapat dilihat pada Tabel 2. Perlakuan dosis pupuk kandang kotoran itik $12,5 \mathrm{t}^{\text {ha }}{ }^{-1}$ menghasilkan bobot basah daun tanaman paling berat yaitu $30,60 \mathrm{~g}$, tidak berbeda dengan $10 \mathrm{t} \mathrm{ha}^{-1}$ dengan hasil 29,16 g tetapi berbeda dengan perlakuan lainnya. 
Rawa Sains: Jurnal Sains STIPER Amuntai, Desember 2011, 1(1), 7-11.

Tabel 2. Nilai uji beda rata-rata bobot basah daun tanaman (g)

\begin{tabular}{cc}
\hline Perlakuan & Rata-rata bobot basah daun tanaman \\
\hline $\mathrm{b}_{0}$ & $16.77_{\mathrm{a}}$ \\
$\mathrm{b}_{1}$ & $17.77_{\mathrm{a}}$ \\
$\mathrm{b}_{2}$ & $21.94_{\mathrm{b}}$ \\
$\mathrm{b}_{3}$ & $24.11_{\mathrm{cd}}$ \\
$\mathrm{b}_{4}$ & $29.16_{\mathrm{e}}$ \\
$\mathrm{b}_{5}$ & $30.60_{\mathrm{e}}$ \\
$\mathrm{b}_{6}$ & $27.10_{\mathrm{d}}$ \\
$\mathrm{b}_{7}$ & $24.83_{\mathrm{c}}$ \\
$\mathrm{b}_{8}$ & $24.05_{\mathrm{c}}$
\end{tabular}

Keterangan : Angka-angka yang di ikuti oleh huruf yang sama tidak berbeda nyata berdasarkan DMRT pada taraf $5 \%$

Berdasarkan hasil analisis ragam tidak terdapat respon tinggi tanaman umur 14, 21 dan 35 HST terhadap perlakuan pemberian pupuk kandang kotoran itik, hal ini diduga karena pada umur tersebut tanaman selada masih dalam fase pertumbuhan yang lambat sehingga tanaman kurang memerlukan unsur hara dikarenakan akar tanaman belum berkembang serta belum aktif menyerap unsur hara. Disamping itu, pupuk kandang seperti bahan organik lainnya yang ditambahkan kedalam tanah tidak dirombak sebagai suatu kesatuan menyeluruh tetapi unsur pokok kimianya dirombak bebas satu dengan lainnya. Hal ini berhubungan dengan laju perombakan bahan organik yang lambat, karena itu unsur hara dapat disimpan Menurut Sitompul dan Guritno (1995) pemberian bahan organik dalam tanah dapat menyebabkan terjadinya immobilisasi nitrogen, dimana terjadinya peningkatan nitrogen oleh mikro-organisme perombak bahan organik yang bersifat sementara dan dilepas kembali begitu perombakan bahan organik selesai (mineralisasi). Adapun $\mathrm{N}$ yang diserap miroorganisme tersebut digunakan sebagai energi untuk merombak bahan organik tersebut.

Terhambatnya suplai unsur $\mathrm{N}$ ketanaman otomatis akan berpengaruh negatif terhadap pertumbuhan daun. Hal ini terbukti pada parameter jumlah daun sampai umur pengamatan 28 HST penambahan pupuk kandang kotoran itik belum memberikan perbedaan pengaruh yang nyata. Menurut Soegito et al. (1995) peran bahan organik sebagai penyuplai unsur hara yang dikandung relatif sedikit. Sebagai contoh perbandingan adalah kadar $\mathrm{N}$ dalam pupuk kandang kotoran itik sekitar 1,00 \% sedangkan urea mencapai 46,00\%.

Dari data di atas maka dapat diketahui bahwa meskipun pemberian pupuk kandang kotoran itik dengan dosis $12,5 \mathrm{t}^{-1}$ memberikan hasil bobot basah daun tanaman yang tertinggi, namun hasilnya tidak berbeda dengan dosis $10 \mathrm{t} \mathrm{ha}^{1}$. Jadi dapat dikatakan bahwa dosis $10 \mathrm{t} \mathrm{ha}^{-1}$ merupakan dosis yang terbaik karena memberikan hasil yang sama dengan dosis pupuk kandang kotoran itik $12,5 \mathrm{tha}^{-1}$ dan pemberian dosis yang lebih besar tidak menjamin peningkatan bobot basah tanaman.

Hasil-hasil penelitian pada tanah sulfat masam menunjukkan pemberian pupuk berpengaruh positif terhadap hasil tanaman. Tanaman yang diberi pupuk lengkap (N, P dan K) menunjukkan lebih baik (Noor, 2004). Pupuk kandang kotoran itik mempunyai kandungan unsur ( $\mathrm{N}, \mathrm{P}$ dan $\mathrm{K}$ ) yang cukup tinggi, sehingga menunjang pertumbuhan selada di lahan rawa lebak.

Nitrogen menunjukkan unsur hara utama bagi pertumbuhan tanaman, sebab merupakan penyusun asam amino, protein dan protoplasma sehingga akan berpengaruh pada pertumbuhan vegetatif tanaman. Nitrogen mempengaruhi proses pembesaran 
Nur Hafizah \& Fikriah, Respon pertumbuhan dan hasil tanaman selada...

sel sehingga tanaman yang mendapatkan jumlah yang cukup akan cenderung berukuran lebih besar dibandingkan tanaman yang mem-peroleh nitrogen dalam jumlah sedikit. Unsur $\mathrm{N}$ yang tinggi akan meningkatkan daya serap akar terhadap unsur hara phosfor dimana unsur hara phosphor berfungsi sebagai perangsang pertumbuhan akar, khususnya pada tanaman muda. Sedangkan unsur hara kalium berfungsi untuk menunjang proses pembentukan akar (Sitompul dan Guritno, 1995).

\section{KESIMPULAN}

\section{Kesimpulan}

Terdapat respon tinggi tanaman sawi umur 28 HST dan bobot basah tanaman sawi tetapi tidak terdapat respon tinggi tanaman sawi umur 14, 21 dan 35 HST terhadap pemberian pupuk kandang kotoran itik dengan dosis terbaik adalah $\mathrm{b}_{4}\left(10\right.$ t.ha $\left.^{-1}\right)$.

\section{DAFTAR PUSTAKA}

Cahyono, B. 2005. Teknik Budidaya dan Analisis Usaha Tani Selada. CV. Aneka ilmu. Semarang.
Direktorat Perluasan Areal. 2005. Petunjuk Teknis Pengolahan Rawa Lebak. Direktorat Jenderal Pengelolaan Lahan dan Air. Jakarta.

Foth. 1998. Dasar-dasar Ilmu Tanah. Gajah Mada Press, Yogyakarta.

Noor, M. 2004. Lahan Rawa Sulfat dan Pengelolaan Tanah Bermasalah Sulfat Masam. Raja Grafindo Persada. Surabaya.

Rukmana R. 1994. Bertanam Selada dan Sawi. Kanisius. Yogyakarta.

Sitompul. S.M. dan Bambang Guritno. 1995. Analisis Pertumbuhan Tanaman. Gadjah Mada University Press. Yogyakarta.

Soegito, Yulia dan Ellis. 1995. Sistem Pertanian Organik. Fakultas Pertanian. Universitas Brawijaya. Malang. 